\title{
Natural diets of lobster Homarus americanus from barren ground and macroalgal habitats off southwestern Nova Scotia, Canada
}

\author{
Robert W. Elner* \& Alan Campbell \\ Invertebrates and Marine Plants Division, Biological Sciences Branch, Department of Fisheries and Oceans, Scotia-Fundy \\ Region, Biological Station, St. Andrews, New Brunswick E0G 2X0, Canada
}

\begin{abstract}
Stomach contents of 1032 lobsters Homarus americanus from an area with dense macroalgae $(\mathrm{n}=115)$ and sea urchin (Strongylocentrotus droebachiensis) denuded barrens $(\mathrm{n}=917)$ off the southwestern coast of Nova Scotia were examined to compare natural diets. Gross dietary composition and mean stomach fullness appeared similar in these 2 habitats; the diet spectrum encompassed a broad range of plants and animals but was dominated by molluscan, crustacean, echinoderm, and polychaete remains. Mussels (Modiolus modiolus, Mytilus edulis) appeared the most consistently important identified prey species, in terms of frequency-of-occurrence and estimated volume (points) indexes. Patterns in prey points were investigated by discriminant analysis. Shifts in point values for gastropods, ascidians, hermit crabs and brachyuran crabs proved useful in discerning habitat. Dietary diversity (mean number of prey taxa types per stomach) was significantly less for lobsters collected on barrens in September 1979 (12.1) than for lobsters taken from the macroalgal area in August 1979 (13.9). Temporal variations in diet were investigated for the barrens. There were significant decreases in mean stomach fullness and mean number of prey taxa types per stomach for lobsters collected in February-March 1982 as opposed to July-August 1981. Concomitantly, temporal shifts in diet composition were evident from discriminant analysis, predominantly through decreased importance of sea urchins, ophiuroids, lobsters, and brachyuran crabs in February-March. Data on the dietary importance of sea urchins in relduion iv vỉè piey tāxa did not support the hypothesis that lobsters are a principal, 'keystone' predator on sea urchins. There is still insufficient evidence to assess whether lobster production is food limited on barrens.
\end{abstract}

\section{INTRODUCTION}

In the present paper we investigate the natural diets of American lobster Homarus americanus from sublittoral barren ground and macroalgal habitats off Nova Scotia, Canada. An explosion in sea urchin Strongylocentrotus droebachiensis densities resulted in destructive grazing of the extensive macroalgal beds along the Atlantic coast of Nova Scotia through at least the 1970 's (Wharton \& Mann 1981). The crustose coralline algae and microalgae on the barren grounds were estimated to be substantially less productive than the kelp communities that they replaced (Chapman 1981). On the basis of the postulated reduced food supply, as well as loss of habitat structure and a corre-

\footnotetext{
- Present address: Department of Fisheries and Oceans, Scotia-Fundy Region, Halifax Fisheries Research Laboratory, PO Box 550, Halifax, Nova Scotia B3J 2S7, Canada

- L. V. Colpitts, Dept. of Biology, Mount Allison Univ., Sackville, New Brunswick E0A 3C0, Canada
}

lation between declining lobster landings and the destruction of the kelp beds, Breen \& Mann (1976) and Wharton \& Mann (1981) concluded that lobster production suffers on the barrens. The lobster, as well as being of prime economic importance along Nova Scotia's coast (Robinson 1980, Stasko \& Campbell 1980) has been purported to have a 'keystone' predator influence (sensu Paine 1969) on the near-shore ecosystem (Mann \& Breen 1972, Breen \& Mann 1976, Bernstein et al. 1983). However, hypotheses for the control of sea urchins by lobsters and the influence of the barrens on lobster feeding have, hitherto, not been examined through natural diet studies for lobsters from either Nova Scotian barren grounds or macroalgal beds.

Lobsters fragment and selectively ingest their prey (R. W. Elner \& L. V. Colpitts " unpubl. data), making studies of their natural diet problematical. Identification of dietary components in the stomachs of lobsters is usually by diagnostic fragments of such relatively 
indigestible skeletal structures as gastropod operculae and crab leg tips (Weiss 1970, Elner et al. 1985). Hence, prey types that include many such fragments may appear over-represented in stomachs compared to prey that are gleaned from their skeletal structures before ingestion or are comparatively soft-bodied and lacking in persistent remnants. Notwithstanding differential selectivity, much ingested food is so masticated that even compiling a complete listing of prey is difficult and ranking prey in order of dietary importance fraught with complications (see Berg 1979, Hyslop 1980 for reviews). The frequency-of-occurrence index and the subjective, estimated volume (points) index appear the only feasible scoring methods for prey in the stomach contents of lobsters and portunid crabs; both methods have been commonly adopted (see Ennis 1973, Scarratt 1980, Carter \& Steele 1982 for lobsters, and Ropes 1968, Elner 1981, Williams 1981 for portunids). While acknowledging that these indexes have their own biases (Hyslop 1980, Williams 1981), they may be used to provide a semi-quantitative ranking of food species in the diets of lobsters.

The natural diets of lobsters from barren ground and macroalgal habitats off southwestern Nova Scotia are recorded in the present paper using extensive data on stomach contents. The significance of habitat and season (for barrens) on stomach fullness, diet diversity, frequency-of-occurrence and points indexes were analyzed by direct comparison as well as by multivariate statistical techniques.

\section{MATERIALS AND METHODS}

Lobsters were taken by SCUBA divers during daylight hours from sea urchin denuded barrens off
McNutts Island, Shelburne Harbour (Fig. 1). In September 1979, July-August 1981, and February-March 1982, 117 (size range 11 to $142 \mathrm{~mm}$ carapace length [CL]), 400 (size range 11 to $78 \mathrm{~mm} \mathrm{CL}$ ), and 400 (size range 8 to $75 \mathrm{~mm} \mathrm{CL}$ ) lobsters respectively were captured. The site was moderately exposed, ranging in depth from 3.0 to $10.0 \mathrm{~m}$ with a substrate consisting of cobbles and boulders densely embedded in a shellsand matrix. Crustose coralline algae Corallina officianalis covered most of the hard substrate in the sublittoral; fleshy macroalgal cover, mainly tufts of Desmarestia spp., was restricted to less than $3 \%$. The narrow infralittoral fringe provided a refuge for Laminaria spp., Alaria spp., and Saccorhiza spp. Sea urchins were the dominant macrofaunal organism, with densities of between 29 and $90 \mathrm{~m}^{-2}$. Other grazers included periwinkles Littorina littorea, limpets Acmaea testudinalis, and chitons Tonicella spp. Mussels Mytilus edulis and Modiolus modiolus, and brittlestars Ophiura spp. were abundant suspension feeders. In addition to lobsters, common predators included seastars Asterias spp., rock crabs Cancer irroratus, Jonah crabs Cancer borealis, and fish.

SCUBA divers collected 115 lobsters (size range 50 to $133 \mathrm{~mm} \mathrm{CL}$ ) from macroalgal beds off Gull Island and Wilson Island, Lobster Bay, during daylight hours in August 1979 (Fig. 1). Substrate, exposure, and depth characteristics of the site resembled those of the barrens. However, as the area had not been destructively grazed by sea urchins, macroalgal cover approached $90 \%$. Irish moss Chondrus crispus was the dominant alga, followed by large kelps Laminaria spp. Sea urchins were rarely found. Gastropods, predominantly Buccinum undatum, bivalves Mytilus edulis and Modiolus modiolus, polychaetes, amphipods, and

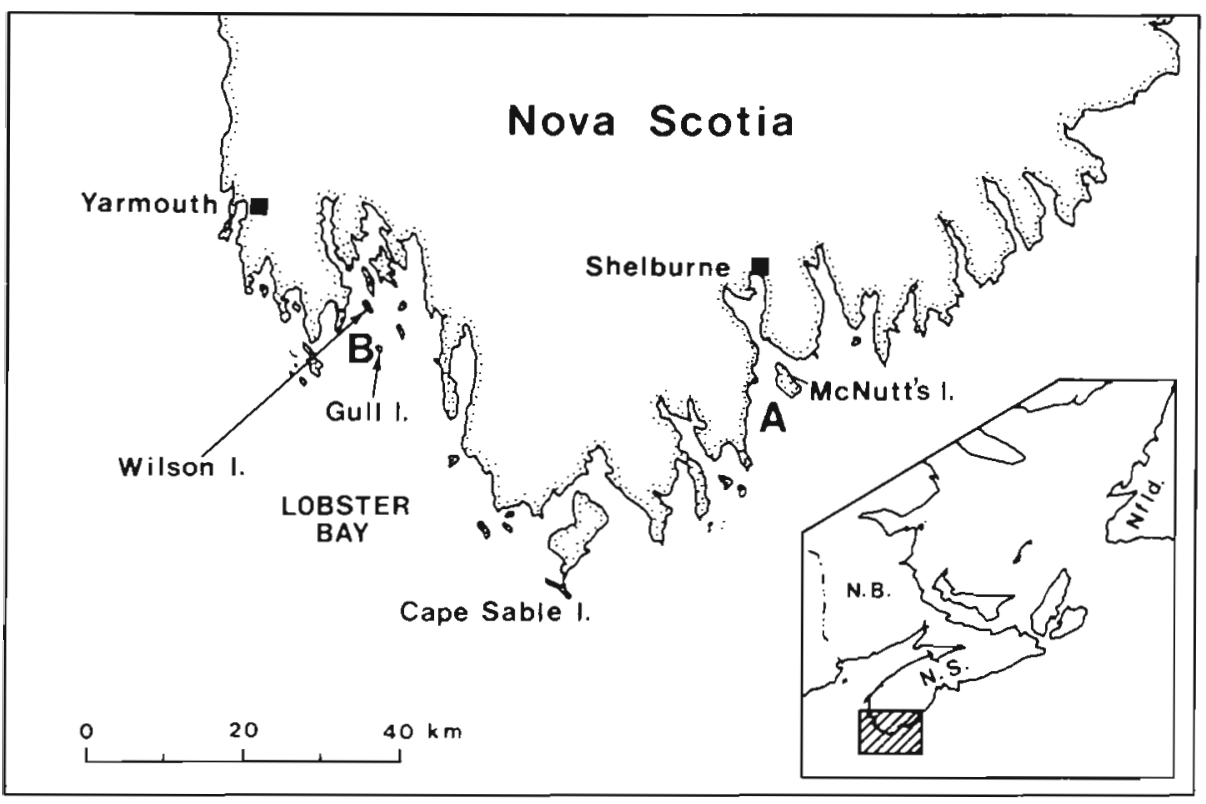

Fig. 1. Maritime provinces of Atlantic Canada (inset); collection sites for Homarus americanus on (A) barrens and (B) macroalgal areas off southwestern Nova Scotia 
crabs Pagurus spp. and Hyas spp. were abundant. Seastars Asterias spp., Cancer crabs, green crabs Carcinus maenas, and lobsters were frequently encountered predators. More detailed biological data for the area are provided by Pringle \& Semple (1980).

Assessments of lobster biomass were not attempted for our study; however, although standardized relative abundance estimates are impractical (given a reduced search efficiency in a kelp bed as compared to an open barrens), the actual lobster collection rates achieved by the SCUBA divers (R. W. Welsford Research Group Limited ' unpubl. report) were similar for the barrens and macroalgal sites in 1979 (barrens: 4.6 lobsters per diver hour; macroalgal area: 4.4 lobsters per diver hour).

On collection, lobsters were sealed in individual plastic bags, together with an information slip including the date and location of capture. The lobsters were then frozen on dry ice and transported in insulated containers to the St. Andrews Biological Station where they were stored in a freezer until required for analyses. After thawing, size was determined for each lobster by measuring carapace length, from the posterior edge of an eye socket to the posterior margin of the carapace. Sex and molt stage (Aiken 1973) were also recorded. The complete stomach sac was excised from the cephalothorax, and stomach fullness was visually estimated according to a scale of 0 to 100 (empty to fully distended). After the stomach was slit open, the contents were flushed out into a Petri dish. Material from the stomach was identified under a hinocular dissecting microscope to the lowest possible taxonomic level. Most food items were recognizable only by the presence of diagnostic fragments; a guide (Elner et al. 1985) to such fragments based on prey remains identified in the stomachs of Cancer crabs from McNutt's Island is also applicable to lobsters. The importance of each prey taxon was evaluated by 2 methods: (1) frequency-of-occurrence; and (2) the points method of Swynnerton \& Worthington (1940), which considers volumetric contribution.

In a given stomach, the frequency-of-occurrence of each prey taxon was recorded on a presence or absence basis. Each prey taxon present was then awarded points based on its estimated volume and in proportion to the total number of points allocated for stomach fullness. For example, a three-quarters full stomach was allocated a total of 75 points; the Cancer spp., making up two-thirds of the bulk, would be awarded 50 points; and the remaining one-third bulk, comprising, say, unidentified plant material, would be given 25 points. Although the visual assessment of stomach

\footnotetext{
- Richard W. Welsford Research Group Ltd, 1860 Upper Water St., Halifax, Nova Scotia B3J 1S9, Canada
}

fullness is subjective and the point 'units' themselves not standardized for stomach size, we believe the method adequately ranks the various prey taxa in terms of dietary bulk. However, differences in digestion rate, feeding behavior, and relative quantity of indicator fragments may enhance the apparent importance of some taxa over others.

Data from both points and frequency-of-occurrence methods were expressed as percentages based on the total number of stomachs that contained food, rather than the total number of stomachs examined. Initially, when comparing points, data within each sample from each of the 4 area-date groups were examined according to sex, $20 \mathrm{~mm}$ CL size class, and molt stage. Almost all lobsters were in intermolt stage; consequently, the few lobsters at pre- or post-molt stages were not considered in our analyses. Analysis of variance (ANOVA) and the Student-Newman-Keuls test (Kim \& Kohout 1975) were used to test for differences between sexes, five $20 \mathrm{~mm}$ CL classes and 4 area-date groups for mean stomach fullness and number of taxa per stomach after arcsine and $\log _{10}$ transformation, respectively. Since there were no significant differences $(p>0.05)$ in mean stomach fullness and number of prey taxa per stomach between sexes and size classes, the data were combined for each area-date group. Weiss (1970) and Ennis (1973) also failed to demonstrate sexual differences in lobster diet. To avoid possible biases caused by empty or near-empty stomachs, only lobsters with stomachs $\geqslant 10 \%$ full were used in the ANOVA's and discriminant analyses; less than $5 \%$ of lobsters were excluded.

To reduce the number of variables considered, the contents of each stomach were reassigned into 26 diet categories. We selected these categories as being the most representative of the 65 taxa originally identified. Utilizing the revised diet categories, frequency-ofoccurrence values were plotted against the points values to allow the relative importance of each category to be visually assessed in each area-date group. Discriminant analysis (Fisher 1936, Kelcka 1975) on points data was chosen for the analysis of variations in the diet categories of the 4 area-date groups. Discriminant analysis, or canonical variate analysis, linearly combines the diet categories in such a way as to maximize the differences between the area-date groups while minimizing the variance within each group. The point scores were arcsine transformed prior to analysis in order to approximate the condition of multinormality which the discriminant analysis assumes; however, this model is robust to some departures from the normal distribution (Legendre \& Legendre 1983). Diet categories with large discriminant coefficients $(\geqslant 0.30)$ within each of the first 2 canonical discriminant functions were considered important in separating the 4 groups. 


\section{RESULTS}

Individual stomach fullness varied considerably in any given lobster size class. Mean stomach fullness was not significantly different between the macroalgal 1979, barrens 1979, and barrens July-August 1981 samples (Table 1). However, mean stomach fullness for barrens in February-March 1982 was significantly lower than those of the other samples (Table 1).

Table 1. Homarus americanus. Mean percent stomach fullness and mean number of taxa per stomach for lobsters from the 4 area-date groups. Retransformed means followed by the same letter in each column are similar ( $p>0.05$ ); means not followed by the same letter in each column are significantly different $(\mathrm{p}>0.01)$ using Student-Newman-Keuls test. Lobsters with $<10 \%$ stomach fullness are excluded

\begin{tabular}{|lccc|}
\hline Area-date & $\begin{array}{c}\text { Mean \% } \\
\text { stomach } \\
\text { fullness }\end{array}$ & $\begin{array}{c}\text { Mean no. of } \\
\text { taxa per } \\
\text { stomach }\end{array}$ & $\mathrm{N}$ \\
\hline Macroalgal: & $55.5 \mathrm{a}$ & 13.9 & 93 \\
$\quad$ Aug 1979 & & & \\
Barrens: & $56.5 \mathrm{a}$ & 12.1 & 110 \\
Sep 1979 & $57.9 \mathrm{a}$ & 10.8 & 389 \\
Jul-Aug 1981 & 29.7 & 7.6 & 377 \\
Feb-Mar 1982 & & & \\
\hline
\end{tabular}

Sixty-five prey taxa were distinguished amongst all the lobster stomachs examined and most were found in both barrens and macroalgal habitats (Table 2). Except for the virtual absence of sea urchins in the sample from macroalgal habitat, the broad dietary composition, both in terms of frequency-of-occurrence and points, appeared remarkably consistent. However, compared to the macroalgal sample, significantly fewer prey taxa per lobster were identified for barren grounds (Table 1). Further, the diet on the barrens for the February-March group was, on average, less diverse than that for July-August, which in turn was less diverse than that for September 1979 (Table 1).

Mussels were consistently one of the most important prey (Table 2). The taxon 'mussels' combined remains of the blue mussel Mytilus edulis and the horse mussel Modiolus modiolus, as the shell fragments of these 2 species were indistinguishable. Nevertheless, given that lobsters are size-selective predators on bivalves (Elner \& Jamieson 1979, Elner \& Lavoie 1983), we argue that $M$. edulis was the more important prey species as it occurred more commonly and in a more vulnerable size range than $M$. modiolus in either habitat.

Unidentified food remains were prominent for all area-date groups (Fig. 2) but were considered proportionately assigned to the remaining identified diet categories and thus effectively ignored. For the macroalgal site, bivalves, ascidians, brachyuran crabs, hermit crabs, gastropods, and lobsters all appeared important in terms of bulk, although unidentified algae/ vascular plants were present the most frequently (Fig. 2). For the barrens in September 1979 bivalves were the dominant dietary component; brachyuran crabs, ophiuroids, lobsters, and seastars were important in terms of points, although they were surpassed by sea urchins, unidentified algae/vascular plants, polychaetes, gastropods, pebbles/foreign material, chitons, fleshy algae, and shrimp/other crustaceans in terms of frequency-of-occurrence (Fig. 2). Bivalves were also the major identified diet category for lobsters captured on the barrens in July-August 1981 and February-March 1982 (Fig. 2). However, while the patterning for most diet categories appeared similar for these latter 2 area-date groups, there were marked shifts in the relative importance of sea urchins and lobsters on both indexes.

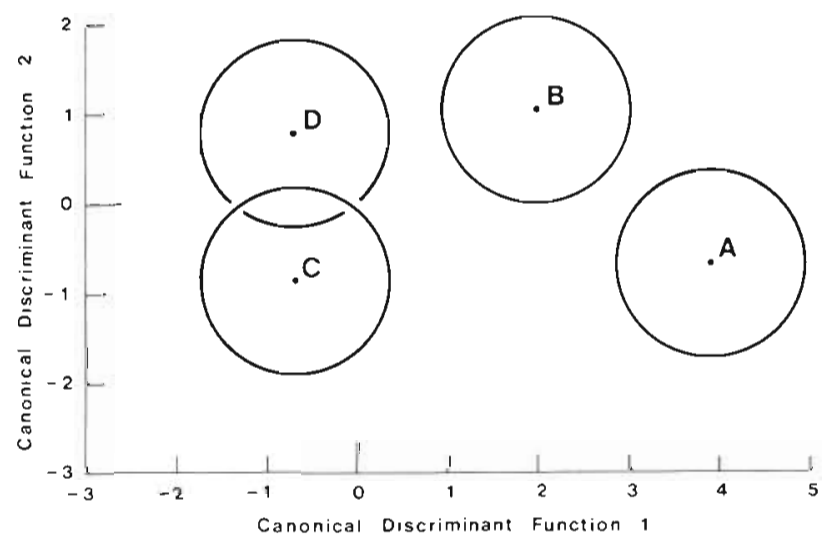

Fig. 3. Homarus americanus. Plot derived from a stepwise discriminant function analysis defining the canonical discriminant function centroids (dots) and \pm 1 standard deviations (circles) for 26 diet categories for the 4 area-date groups (stomachs $\geqslant 10 \%$ full): A, macroalgae, Aug 1979; B, barrens, Sep 1979; C, barrens, Feb-Mar 1982; D, barrens, Jul-Aug 1981. Individual data points $(N=969)$ were omitted, as they are too numerous

Discriminant analysis on the diet of 969 lobsters indicated significant differences between the 4 areadate groups (Fig. 3; Table 3). The first canonical discriminant function represented the largest variance $(70 \%)$ between the 4 area-date groups (Table 3$)$. The 5 variables with the largest coefficients $(\geqslant 0.30)$, giving the best discrimination between the groups (in decreasing order), were gastropods, ascidians, hermit crabs, gravel, and brachyuran crabs. The first function was generally useful in discriminating spatial (area) differences between the groups. The second canonical discriminant function (representing $21 \%$ of variance between groups) was mostly influenced by echinoids, 
Table 2. Homarus americanus. Occurrence of prey taxa in stomachs by percentage frequency-of-occurrence (percentage points) for the 4 area-date groups: A, macroalgal Aug $1979(\mathrm{n}=115)$; B, barrens, Sep $1979(\mathrm{n}=117)$; C, barrens, Jul-Aug 1981 ( $\mathrm{n}=400)$; D, barrens, Feb-Mar $1982(n=400)$

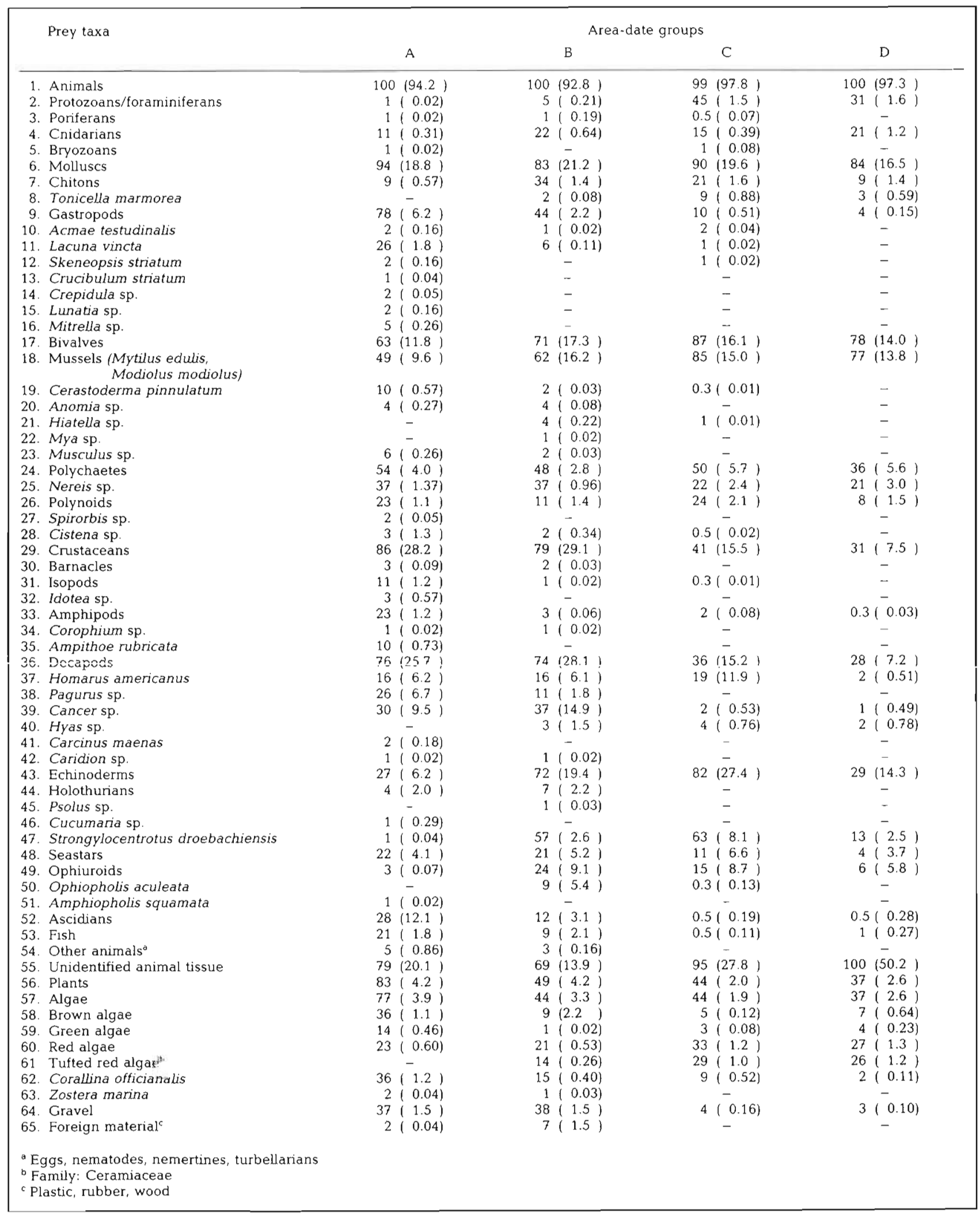



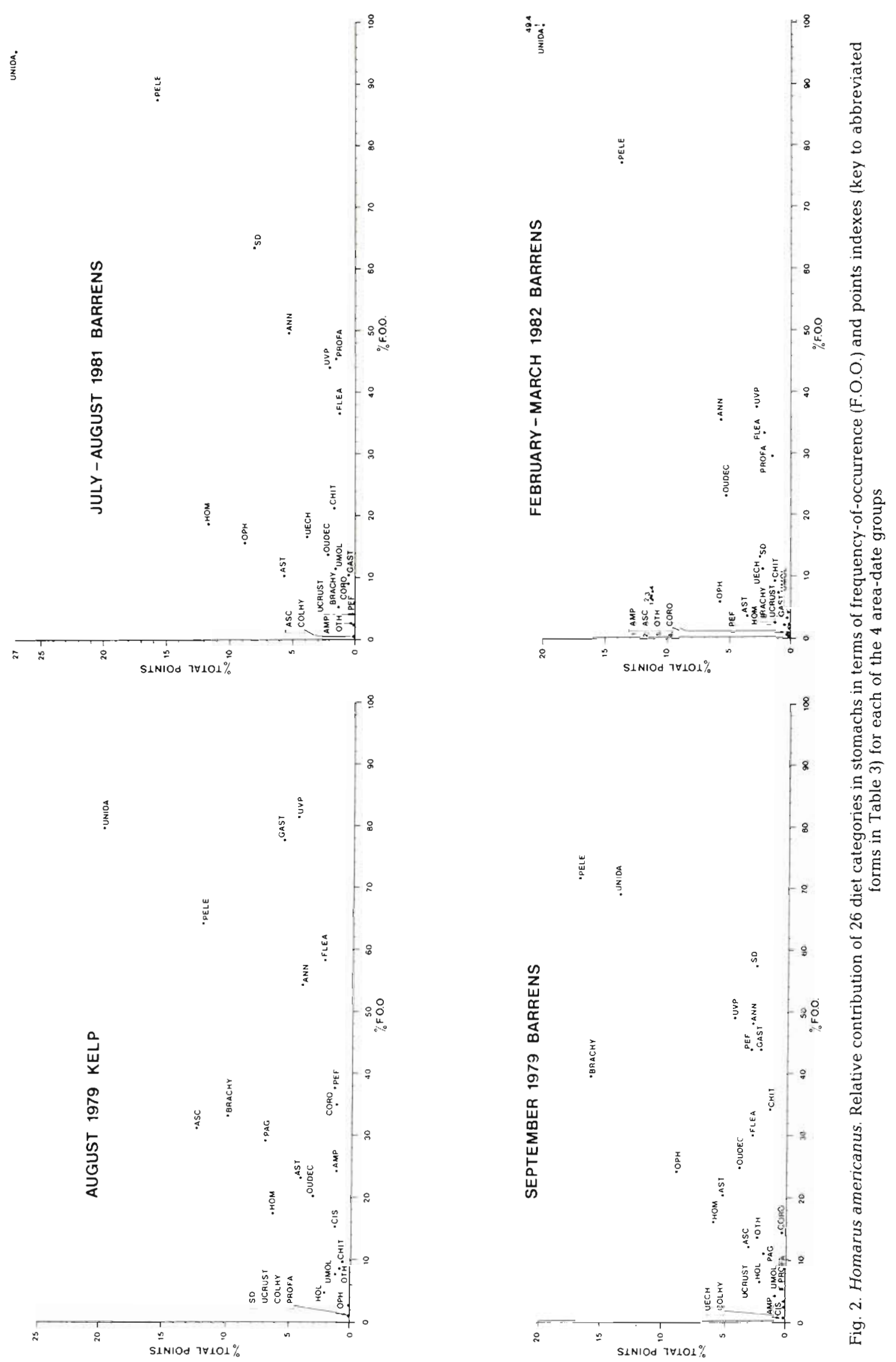
Table 3. Homarus americanus. Coefficients of the canonical discriminant functions for 26 diet categories (abbreviations for Fig. 2) from the 4 area-date groups. Coefficients have decimal places removed (e.g. $-24=-0.24)$. Lobsters with < $10 \%$ stomach fullness are excluded

\begin{tabular}{|c|c|c|c|}
\hline \multirow[t]{2}{*}{ Diet category } & \multicolumn{3}{|c|}{ Standardized canonical discriminant coefficients } \\
\hline & Function 1 & Function 2 & Function 3 \\
\hline 1. Protozoa/foraminiferans (PROFA) & -24 & 06 & 19 \\
\hline 2. Cnidarians (COLHY) & -08 & -00 & 09 \\
\hline 3. Unidentified molluscs (UMOL) & -07 & -03 & 10 \\
\hline 4. Chitons (CHIT) & -04 & 08 & -26 \\
\hline 5. Gastropods (GAST) & 58 & 02 & 10 \\
\hline 6. Bivalves (PELE) & 02 & 24 & 14 \\
\hline 7. Polychaetes (ANN) & 04 & 18 & 25 \\
\hline 8. Unidentified crustaceans (UCRUST) & 07 & 08 & -11 \\
\hline 9. Cirripeds/isopods (CIS) & 15 & -14 & 24 \\
\hline 10. Amphipods (AMP) & 18 & -09 & 33 \\
\hline 11. Shrimps/other crustaceans (OUDEC) & 13 & -08 & -07 \\
\hline 12. Lobsters (HOM) & 15 & 30 & 26 \\
\hline 13. Hermit crabs (PAG) & 37 & 03 & 17 \\
\hline 14. Brachyuran crabs (BRACHY) & 32 & 30 & -28 \\
\hline 15. Unidentified echinoderms (UECH) & -09 & 24 & 26 \\
\hline 16. Holothurians (HOL) & 12 & 11 & -16 \\
\hline 17. Echinoids ${ }^{d}$ (SD) & 17 & 75 & 08 \\
\hline 18. Asteroids (AST) & 08 & 25 & 13 \\
\hline 19. Ophiuroids (OPH) & 04 & 34 & 12 \\
\hline 20. Ascidians (ASC) & 40 & -01 & 22 \\
\hline 21. Unidentified animal tissue (UNIDA) & -08 & 01 & 26 \\
\hline 22. Unidentified algae/vascular plants (UVP) & 18 & -03 & -14 \\
\hline 23. Fleshy algae (FLEA) & -10 & -03 & 32 \\
\hline 24. Coraline algae (CORO) & 07 & -03 & 27 \\
\hline 25. Gravel/foreign (PEF) & 36 & 18 & -38 \\
\hline 26. Other $(\mathrm{OTH})$ & 16 & 10 & -20 \\
\hline Percent variance & 69.9 & 21.0 & 9.1 \\
\hline Eigenvalue & 2.29 & 0.69 & 0.30 \\
\hline Canonical correlation & 0.834 & 0.638 & 0.481 \\
\hline Wilk's $\lambda$ & $0.138^{\mathrm{b}}$ & $0.456^{\mathrm{b}}$ & $0.769^{\mathrm{b}}$ \\
\hline $\begin{array}{l}{ }^{a} \text { Strongylocentrotus droebachiensis } \\
\mathrm{p}<0.01\end{array}$ & & & \\
\hline
\end{tabular}

ophiuroids, lobsters, and brachyuran crabs. This second function appeared useful in discriminating temporal (date) differences between groups.

An a posteriori classification of individual lobster stomachs was used to estimate the discriminating power and classification accuracy of the derived canonical discriminant functions. The total percent of 'grouped' cases correctly classified into their appropriate area-date groups was $76.4 \%$.

\section{DISCUSSION}

Stomach contents of lobsters from barren grounds and macroalgal beds off southwestern Nova Scotia appear remarkable, not for differences but, rather, for their broad consistency. The natural diets of the lobsters studied from both habitats, although comprising a diverse spectrum of benthic prey, tended to be domi- nated by the same major components: echinoderms, molluscs, and polychaetes. In particular, mussels were invariably the most important identified prey for all sampling areas and dates. However, notwithstanding the overall pattern, some habitat-related differences in natural diet were detected. Lobster diet diversity was higher for the macroalgal habitat than the barrens (Table 1), and area-date groups could be effectively separated by multivariate analyses (Table 3; Fig. 3). The diet categories most influential for area discrimination (gastropods, ascidians, hermit crabs, and brachyuran crabs) do change, markedly in dietary rank and abundance (B. Michaud * unpubl. data), between the 2 habitat-types. Nevertheless, the diet diversity differences and prey shifts responsible for group discrimination are not necessarily of dietary importance

- B. Michaud, Dept. of Oceanography, Dalhousie Univ., Halifax, Nova Scotia B3H 4J1, Canada 
per se, and their functional significance remains to be tested. Indeed, 'gravel' was also a major discriminator for habitat. We, like Herrick (1895), remain nonplussed by the incidence of gravel in lobster stomachs but suggest it is probably ingested coincidentally while the lobster is feeding on more nourishing prey.

Previous studies of the natural diet of the American lobster from various parts of the western Atlantic appear in general agreement with our study in that crabs, echinoderms, mussels, and polychaetes have also been found to be dominant prey (Squires 1970, Weiss 1970, Ennis 1973, Scarratt 1980, Carter \& Steele 1982). Such dietary consistency, as well as being in accord with interhabitat comparisons (above), is noteworthy given the probable geographic changes in the relative abundances of prey species over the lobsters' range. The implication is that lobsters are selective feeders with a complex foraging behavior that is capable of maintaining gross diet composition despite sharp variations in prey availability. Certainly the contentions of previous workers that lobsters are either simple opportunistic omnivores whose stomach contents reflect the relative abundance of prey species in the habitat' (Miller et al. 1971) or 'scavengers' (Herrick 1895) and 'most unspecialized feeders' consuming 'almost anything, regardless of its possible nutritional value' (Scarratt 1980) should now be reassessed.

Considering our results in tandem with studies by Vadas et al. (1986) on the influence of lobsters on sea urchin behavior and interpretive reviews on western Atlantic coastal ecology (Pringle et al. 1982, Miller 1985a, Sebens 1985) we argue that lobsters are unlikely agents in the transformation of macroalgal beds to barrens, and there is insufficient evidence to assess whether lobster production is adversely affected by the barren state. The initial explosion of sea urchin densities associated with destructive grazing has been accorded to a decline in a principal keystone predator, the lobster (Mann \& Breen 1972, Breen \& Mann 1976 , Mann 1977). Sea urchins were rare in the macroalgal habitat, and their remains were found in only one out of 115 lobster stomachs examined. Although sea urchins were more prominent in the stomachs of lobsters from barrens, a habitat where urchins were the most common macrofaunal organism, they were of variable rank and always surpassed in importance by other prey, particularly mussels. Intuitively, in a keystone interaction, sea urchins should be a strongly preferred prey in both the barrens and macroalgal habitats; we contend that such a preference is not reflected by the dietary rank of sea urchins in our samples. Similarly, laboratory experiments (Evans \& Mann 1977, Hirtle \& Mann 1978, Elner 1980) have consistently shown that lobsters do not exhibit a preference for sea urchins when alternative prey are avail- able. Moreover, our data do not concur with the contention by Wharton \& Mann (1981) that lobsters from barren grounds experience a critical lack of food. Given that our lobster collection rate data are indicative of lobster biomass densities being similar in both habitats (see also Miller 1985a), there appear to be sufficient standing biomass and production inputs on the barrens to maintain the lobster food supply, in terms of general prey composition and bulk. Indeed, as Miller et al. (1971) determined that food production in the seaweed zone of St. Margarets Bay, Nova Scotia, was an order of magnitude greater than that needed to support the local lobster stock, we would not expect a $60 \%$ reduction in primary productivity (Chapman 1981), in itself, to be necessarily critical.

Temporal variations in the natural diet of lobsters have been detected in other investigations (Weiss 1970, Carter \& Steele 1982) as well as our own. For barrens in the present study, sea urchin, ophiuroid, lobster, and brachyuran crab remains all decreased in importance between July-August 1981 and FebruaryMarch 1982; indeed, these shifts were most useful in discriminating date differences between samples (Table 3). Such effects may be due to seasonal changes in both foraging activity and the availability of prey species. For example, sea urchins show seasonal variations in distribution and behavior (Bernstein et al. 1981), and crabs undergo seasonal movements and become more vulnerable during their molting period (R. W. Elner unpubl. data). Lobsters suffer an increased vulnerability during their molting period as well as demonstrating molt-related shifts in diet (Ennis 1973, Leavitt et al. 1979, Scarratt 1980). Lobster remains have also been encountered in lobster stomachs in other studies (Weiss 1970, Carter \& Steele 1982); although we determined that some remains could have been from cast exuviae, others, associated with flesh, indicated that cannibalism was occurring. The significant reduction in mean stomach fullness in FebruaryMarch (Table 1) could be attributed to a depression in feeding activity due to low sea temperature. A similar seasonal reduction in stomach fullness for lobsters was found by Ennis (1973), but not by Carter \& Steele (1982).

The same prey types tend to be found in the stomachs of juvenile lobsters as are encountered in adults; and, although the incidence of the various types may differ (Scarratt 1980, Carter \& Steele 1982), diet variations related to lobster size are claimed to be minor (Weiss 1970). However, size-related phenomena could explain the relatively high importance of brachyuran crabs and gastropods in the diet of lobsters collected on the barrens in September 1979 compared to the reduced importance of the same diet categories for the smaller barren ground lobsters in July-August 
1981. These changes in diet indicate that larger lobsters have a relatively wider range of food supplies available to them: the more open foraging mode adopted by larger lobsters (Lawton 1987) is commensurate with the pursuit of mobile prey such as crabs; similarly, their stronger chelae (Elner \& Campbell 1981) would enable them to crush both a wider size range of invertebrates (Elner \& Jamieson 1979, Elner 1980, Elner \& Lavoie 1983) and more heavily armoured species, such as gastropods, than their smaller conspecifics.

The frequency of occurrence and volume of plant material in the lobster stomachs, even those from barrens, suggest that plants are not merely ingested coincidentally with invertebrate prey but, rather, are actively sought and form a functional nutritional component. Previous authors have found plant material in the natural diet of Homarus americanus (Herrick 1895, Weiss 1970, Ennis 1973, Scarratt 1980, Carter \& Steele 1982) as well as in other decapod crustaceans (Elner 1981, Williams 1981, Joll \& Phillips 1984). Indeed, seaweeds have been reported as the major food of various spider crabs (Hartnoll 1963) and a portunid Liocarcinus puber (Choy 1986). Syslo \& Hughes (1981) determined that seaweeds can be substituted for more expensive animal protein in diets for cultured $H$. americanus and result in comparable growth. However, the mechanism by which seaweeds contribute to lobster growth and the role of plant material in natural diets remains to be elucidated. Discussion by Joll \& Phillips (1984) on the possible significance of plant material in the diet of the western rock lobster Panulirus cygnus, as well as the additional possibility that coralline algae contributes to calcium requirements, may be of relevance to $H$. americanus.

In conclusion, we are in agreement with Livingstone (1985) on the need to encourage and develop food habit studies. Apart from being a valuable tool, in tandem with natural history observations, in elucidating ecosystem interactions, the data provide a base to understanding relationships between prey availability and predator production. Long-term field investigations of lobster growth and population dynamics are now necessary to definitively test the effects of habitat on lobster production. To fully understand the ecological mechanisms involved, future workers will also have to consider size-specific feeding aspects and relate the biomass, density, and size distribution of lobsters with the same parameters for the prey. Studies of west coast rock lobster Jasus lalandii off southern Africa have suggested that food availability is probably the most important factor limiting growth rate (Pollock \& Beyers 1981). Natural diet data from juvenile western rock lobsters Panulirus longipes cygnus off southern Western Australia failed to support the hypothesis of Chittleborough (1976) that food supply influences growth between sex/age-class groups but did indicate that diet was the cause of growth differences between 2 sites (Joll \& Phillips 1984).

Acknowledgements. We thank the Richard W. Welsford Research Group Ltd for diving expertise, and L. E. Linkletter for taxonomic skills, K. Booth, L. V. Colpitts, C. A. Gass, and D. A. Robichaud gave careful technical assistance. We are grateful to G. Fawkes for computing; G. Jeffrey, P.W. G. McMullon, and F. B. Cunningham for drafting; and B. Fawkes for typing the manuscript. J. D. Castell, R. N. Hughes, P. Lawton, and R. J. Miller provided valuable criticism of the study.

\section{LITERATURE CITED}

Aiken, D. E. (1973). Proecdysis, setal development, and molt prediction in the American lobster (Homarus americanus). J. Fish. Res. Bd Can. 30: 1337-1344

Berg, J. (1979). Discussion of methods of investigating the food of fishes, with reference to a preliminary study of the prey of Gobiusculus flavescens (Gobiidae). Mar. Biol. 50: 263-273

Bernstein, B. B., Schroeter, S. C., Mann, K. H. (1983). Sea urchin (Strongylocentrotus droebachiensis) aggregating behavior investigated by a subtidal multifactorial experiment. Can. J. Fish. Aquat. Sci. 40: 1975-1986

Bernstein, B. B., Williams, B. E., Mann, K. H. (1981). The role of behavioral responses to predators in modifying urchins (Strongylocentrotus droebachiensis) destructive grazing and seasonal foraging patterns. Mar. Biol. 63: 39-49

Breen, P. A., Mann, K. H. (1976). Changing lobster abundance and the destruction of kelp beds by sea urchins. Mar. Biol. 34: $137-142$

Carter, J. A., Steele, D. H. (1982). Stomach contents of immature lobsters (Homarus americanus) from Placentia Bay, Nowfoundland. Can. I. Zoo!. 60: 337-347

Chapman, A. R. O. (1981). Stability of sea urchin dominated barren grounds following destructive grazing of kelp in St. Margaret's Bay, eastern Canada. Mar, Biol. 62: 307-311

Chittleborough, R. G. (1976). Growth of juvenile Panulirus longipes cygnus George on coastal reefs compared with those reared under optimal environmental conditions. Aust. J. mar. Freshwat. Res. 27: 279-295

Choy, S. C. (1986). Natural diet and feeding habits of the crabs Liocarcinus puber and $L$. holsatus (Decapoda, Brachyura, Portunidae). Mar. Ecol. Prog. Ser. 31: 87-99

Elner, R. W. (1980). Predation on the sea urchin (Strongylocentrotus droebachiensis) by the American lobster (Homarus americanus) and the rock crab (Cancer irroratus). In: Pringle, J. D., Sharp, G. J., Caddy, J. F. (ed.) Proceedings of the workshop on the relationship between sea urchin grazing and commercial plant/animal harvesting. Can. Tech. Rep. Fish. Aquat. Sci. 954: 48-65

Elner, R. W. (1981). Diet of green crab Carcinus maenas (L.) from Port Hebert, southwestern Nova Scotia. J. Shellfish Res. 1: 89-94

Elner, R. W., Campbell, A. (1981). Force, function and mechanical advantage in the chelae of the American lobster Homarus americanus (Decapoda: Crustacea). J. Zool. Lond. 193: 269-286

Elner, R. W., Jamieson, G. S. (1979). Predation of sea scallops, Placopecten magellanicus, by the rock crab, Cancer irroratus, and the American lobster, Homarus americanus. J. Fish. Res. Bd Can. 36: 537-543

Elner, R. W., Lavoie, R. E. (1983). Predation on American 
oysters (Crassostrea virginica [Gmelin]) by American lobsters (Homarus americanus Milne-Edwards), rock crabs (Cancer irroratus Say), and mud crabs (Neopanope sayi [Smith]). J. Shellfish Res. 3: 129-134

Elner, R. W., Beninger, P. G., Linkletter, L. E., Lanteigne, S (1985). Guide to indicator fragments of principal prey taxa in the stomachs of two common Atlantic crab species: Cancer borealis Stimpson, 1859 and Cancer irroratus Say 1817. Can. Tech. Rep. Fish. Aquat. Sci. 1403: 1-20

Ennis, G. P. (1973). Food, feeding, and condition of lobster, Homarus americanus, throughout the seasonal cycle in Bonavista Bay, Newfoundland. J. Fish. Res. Bd Can. 30: 1905-1909

Evans, P. D., Mann, K. H. (1977). Selection of prey by American lobsters (Homarus americanus) when offered a choice between sea urchins and crabs. J. Fish. Res. Bd Can. 34 2203-2207

Fisher, R. A. (1936). The use of multiple measurements in taxonomic problems. Ann. Eugen. 7: 179-188

Hartnoll, R. G. (1963). The biology of Manx spider crabs. Proc. zool. Soc., Lond. 141: 423-496

Herrick, F. H. (1895). The American lobster: a study of its habits and development. Bull. U.S. Fish Commn 15: 1-252

Hirtle, R. W. M., Mann, K. H. (1978). Distance chemoreception and vision in the selection of prey by American lobster (Homarus americanus). J. Fish. Res. Bd Can. 35: 1006-1008

Hyslop, E. J. (1980). Stomach content analysis - a review of methods and their application. J. Fish Biol. 17: 411-429

Joll, L. M., Phillips, B. F. (1984). Natural diet and growth of juvenile western rock lobsters Panulirus cygnus George. J. exp. mar. Biol. Ecol. 75: 145-169

Kelcka, W. R. (1975). Discriminant analysis. In: Nie, N. H., Hull, C. H., Jenkins, J. G., Steinbrenner, K., Bert, D. H. (ed.) Statistical package for the social sciences, 2nd edn. McGraw-Hill, New York, p. 434-467

Kim, J. O., Kohout, P. J. (1975). Analysis of variance and covariance: subprograms ANOVA and ONE-WAY. In: Nie, N. H., Hull, C. H., Jenkins, J. G., Steinbrenner, K., Bert, D. H. (ed.) Statistical package for the social sciences, 2nd edn. McGraw-Hill, New York, p. 398-433

Lawton, P. (1987). Diel activity and foraging behavior of juvenile American lobsters, Homarus americanus. Can. J. Fish. Aquat. Sci. 44: in press

Leavitt, D. F., Bayer, R. C., Gallagher, M. L., Rittenburg, J. H. (1979). Dietary intake and nutritional characteristics in wild American lobsters (Homarus americanus). J. Fish. Res. Bd Can. 36: 965-969

Legendre, L., Legendre, P. (1983). Numerical ecology. Developments in environmental modelling, Vol. 3. Elsevier Scientific Publishing Co., New York

Livingston, P. A. (1985). An ecosystem model evaluation: the importance of fish food habit data. Mar. Fish. Rev. 47: 9-12

Mann, K. H. (1977). Destruction of kelp beds by sea urchins: a cyclical phenomenon or irreversible degradation? Helgoländer wiss. Meeresunters. 30: 455-467

Mann, K. H., Breen, P. A. (1972). The relation between lobster abundance, sea urchins and kelp beds. J. Fish. Res. Bd Can. 29: 603-609

Miller, R. J. (1985a). Seaweeds, sea urchins and lobsters: a reappraisal. Can. J. Fish. Aquat. Sci. 42: 2061-2072

Miller, R. J. (1985b). Succession in sea urchin and seaweed abundance in Nova Scotia, Canada. Mar. Biol. 84: 275-286

Miller, R. J., Mann, K. H., Scarratt, D. J. (1971). Production potential of a seaweed-lobster community in eastern Canada. J. Fish. Res. Bd Can. 28: 1733-1738

Paine, R. T. (1969). A note on trophic complexity and community stability. Am. Nat. 103: 91-93

Pollock, D. E., DeB. Beyers, C. J. (1981). Environment, distribution and growth rates of west coast rock-lobster Jasus lalandi (H. Milne-Edwards). Trans. R. Soc. S. Afr. 44: $379-400$

Pringle, J. D., Semple, R. E. (1980). The benthic algal biomass, commercial harvesting, and Chondrus growth and colonization off southwestern Nova Scotia. In: Pringle, J. D., Sharp, G. J., Caddy, J. F. (ed.) Proceedings of the workshop on the relationship between sea urchin grazing and commercial plant/animal harvesting. Can. Tech. Rep. Fish. Aquat. Sci. 954: 144-169

Pringle, J. D., Sharp, G. J., Caddy, J. F. (1982). Interactions in kelp bed ecosystems in the northwest Atlantic: review of a workshop. In: Mercer, M. C. (ed.) Multispecies approaches to fisheries management advice. Can. Spec. Publ. Fish. Aquat. Sci. 59: 108-115

Robinson, D. G. (1980). History of the lobster fishery on the eastern shore of Nova Scotia. In: Pringle, J. D., Sharp, G. J., Caddy, J. F. (ed.) Proceedings of the workshop on the relationship between sea urchin grazing and commercial plant/animal harvesting. Can. Tech. Rep. Fish. Aquat. Sci. 954: 8-23

Ropes, J. W. (1968). The feeding habits of the green crab, Carcinus maenas (L.). Fish. Bull. U.S. 67: 183-203

Scarratt, D. J. (1980). The food of lobsters. In: Pringle, J. D., Sharp, G. J., Caddy, J. F. (ed.) Proceedings of the workshop on the relationship between sea urchin grazing and commercial plant/animal harvesting. Can. Tech. Rep. Fish. Aquat. Sci. 954: 66-91

Sebens, K. P. (1985). The ecology of the rocky subtidal zone. An. Scient. 736: 548-557

Squires, H. J. (1970). Lobster (Homanus americanus) fishery and ecology in Port au Port Bay, Newfoundland, 1960-65. Proc. natn. Shellfish. Ass. 60: 22-39

Stasko, A. B., Campbell, A. (1980). An overview of lobster life history and fishery in southwestern Nova Scotia. In: Pringle, J. D., Sharp, G. J., Caddy, J. F. (ed.) Proceedings of the workshop on the relationship between sea urchin grazing and commercial plant/animal harvesting. Can. Tech. Rep. Fish. Aquat. Sci. 954: 208-224

Swynnerton, G. H., Worthington, E. B. (1940). Note on the food of fish in Haweswater (Westmorland). J. Anim. Ecol. 9: $183-187$

Syslo, M., Hughes, J. T. (1981). Vegetable matter in lobster (Homarus americanus) diets (Decapoda, Astacidae). Crustaceana 41: 10-13

Vadas, R. L., Elner, R. W., Garwood, P. E., Babb, I. G. (1986) Experimental evaluation of aggregation behavior in the sea urchin Strongylocentrotus droebachiensis: a reinterpretation. Mar. Biol. 90: 433-448

Weiss, H. M. (1970). The diet and feeding behavior of the lobster, Homarus americanus, in Long Island Sound. Ph.D. thesis, University of Connecticut, Storrs

Wharton, W. G., Mann, K. H. (1981). Relationship between destructive grazing by the sea urchin, Strongylocentrotus droebachiensis, and the abundance of American lobster, Homarus americanus, on the Atlantic coast of Nova Scotia. Can. J. Fish. Aquat. Sci. 38: 1339-1349

Williams, M. J. (1981). Methods for analysis of natural diet in portunid crábs (Crustacea: Decapoda: Portunidae). J. exp. mar. Biol. Ecol. 52: 103-113 